Bull. Mater. Sci., Vol. 17, No. 6, November 1994, pp. 849-853. (C) Printed in India.

\title{
Synthesis of aluminium matrix composites containing nanocrystalline oxide phases
}

\author{
S K PRADHAN, A DATTA, A CHATTERJEE ${ }^{\dagger}, M$ DE and \\ D CHAKRAVORTY \\ Indian Association for the Cultivation of Science, Jadavpur, Calcutta 700 032, India \\ ${ }^{\dagger}$ Present address: Research and Consultancy Directorate, The Associated Cement Companies \\ Ltd., Thane 400604 , India
}

\begin{abstract}
Using nanocrystalline particles of mullite and zirconia respectively with diameters in the range $20-30 \mathrm{~nm}$ prepared by a sol-gel route, aluminium metal-matrix composites have been synthesized. A hot pressing technique has been used with temperatures varying from $450-610^{\circ} \mathrm{C}$. The vickers hardness values for the composites are found to be substantially higher than that of pure aluminium. An order of magnitude increase in hardness is achieved when $\mathrm{Al}_{5} \mathrm{Mo}$ phase is grown in the composite.
\end{abstract}

Keywords. Nanocrystalline; mullite; zirconia; aluminium; composites.

\section{Introduction}

Aluminium-based metal-matrix composites have received increasing attention in recent years for potential applications in structural parts (Marsden 1985; Ohtsu 1989) and engine components (Flinn 1990; Lampman 1991). In most of the investigations reported, improvement of mechanical properties has been studied in systems consisting of ceramic particulates or whiskers dispersed in an aluminium matrix (Lee and Subramanian 1993; Pandey et al 1993). In all the work referred to above the size of the ceramic particles has been of the order of a few micrometers. We have prepared aluminium based metal-matrix composites containing nanometer sized particles of mullite and zirconia respectively. To our knowledge synthesis of such composites has not been reported earlier. We have carried out hardness measurements on the synthesized samples. A marked increase in the hardness value has been observed in specimens containing nanocrystalline oxides as compared to that of pure aluminium. The preliminary results are described in this paper.

\section{Experimental}

Nanocrystalline mullite was prepared by a sol-gel method. The starting materials were AR grade $\mathrm{Al}\left(\mathrm{NO}_{3}\right)_{3} \cdot 9 \mathrm{H}_{2} \mathrm{O}$ and $\mathrm{Si}\left(\mathrm{OC}_{2} \mathrm{H}_{5}\right)_{4}$ of appropriate amounts. The gel powder obtained from the precursor sol was hot pressed in a DSP 25 ATS Sintering Press (manufactured by M/s Dr Fritsch Sondermaschinen, Germany) at a temperature of $750^{\circ} \mathrm{C}$ for $5 \mathrm{~min}$ under a pressure of 24 bar. The details of synthesis have been reported earlier (Pradhan et al 1994). For the synthesis of nanocrystalline zirconia the starting material was $\mathrm{ZrOCl}_{2} \cdot 8 \mathrm{H}_{2} \mathrm{O}$. To a solution of the latter distilled water aqueous ammonia was added dropwise to bring about a.complete precipitation of $\mathrm{Zr}(\mathrm{OH})_{4}$. By suitable heat treatment of the filtered mass nanocrystalline $\mathrm{ZrO}_{2}$, 
comprising of cubic, tetragonal and monoclinic phases, respectively were obtained. The details are reported elsewhere (Chatterjee et al 1994).

For preparation of the aluminium metal matrix composites in the present investigation the required amount of commercial grade aluminium powder (of $99.7 \%$ purity) was mixed with $\sim 23$ volume\% of the oxide particulates viz. $\mathrm{ZrO}_{2}$ and mullite, respectively synthesized as described in the previous section. The volume fraction of the ceramic phase as mentioned above was chosen because optimum mechanical properties were reported in literature for conventional metal matrix composites for this value (Patnolli and Zaffanini 1991). The mixture consisting of aluminium metal and ceramic powders was ground in a mortar under acetone for about $2 \mathrm{~h}$. The mixture was then subjected to vigorous stirring in an ultrasonic bath. The mixed powder was then taken in a graphite mould. The latter was mounted in a DSP 25 ATS Sintering Press supplied by M/s Dr Fritsch Sondermaschinen, Germany. The pressing was done in an evacuated chamber with a pressure of 0.26 bar at temperatures varying from $450-610^{\circ} \mathrm{C}$ with an applied pressure of 24 bar for a duration of $2 \mathrm{~min}$. Some specimens were also prepared by covering the mixed powder of aluminium and nanocrystalline oxide with molybdenum foils with a thickness of $\sim 25 \mu \mathrm{m}$ during the hot pressing operation.

The various crystalline phases in the composites synthesized were determined from the X-ray diffractograms taken in a Phillips X-ray diffractometer. (PW 1710) using $\mathrm{CuK}_{\alpha}$ radiation. The particle sizes of the different phases were determined using Scherrer equation (Klug and Alexander 1974). We have used pure aluminium as instrumental standard. Step scan data of instrumental and sample profiles were fitted analytically using pseudo-Voigt function and full width at half maxima (FWHM) was estimated after complete peak separation for at least first four reflections of aluminium (Enzo et al 1988). In our samples the particle size of aluminium was found to be $\sim 1.5 \mu \mathrm{m}$. The sizes of mullite and zirconia particles were estimated to be $20 \mathrm{~nm}$ and $29 \mathrm{~nm}$ respectively. The microhardness of the specimens prepared after polishing the surface with $1 \mu \mathrm{m}$ diamond paste was investigated by the Vickers microhardness tester (model mph 160) attached to a high resolution optical microscope (Carl Zeiss Jenavert) with a DIK attachment. The indentations were carried out at a given load and the Vickers hardness $H_{\mathrm{v}}$ was obtained from the relation

$$
H_{\mathrm{v}}=1.8544 \frac{P}{d^{2}},
$$

where $P$ is the applied load in kilograms and $d$ the diagonal measure of indentation in $\mathbf{m m}$.

\section{Results and discussion}

Figure 1 shows the $\mathrm{X}$-ray diffractograms of the different composites prepared in this work. It is evident that samples 1 to 6 contain $\alpha-\mathrm{Al}_{2} \mathrm{O}_{3}$ besides the mullite phase. Also, for the sample hot pressed at $610^{\circ} \mathrm{C}$ with a molybdenum foil covering the starting mixture of aluminium and the oxide phase, the growth of the intermetallic phase $\mathrm{Al}_{5} \mathrm{Mo}$ takes place. Such low temperature formation of $\mathrm{Al}_{5} \mathrm{Mo}$ is ascribed to an increase in kinetics for the formation of this phase at high pressure. For samples 


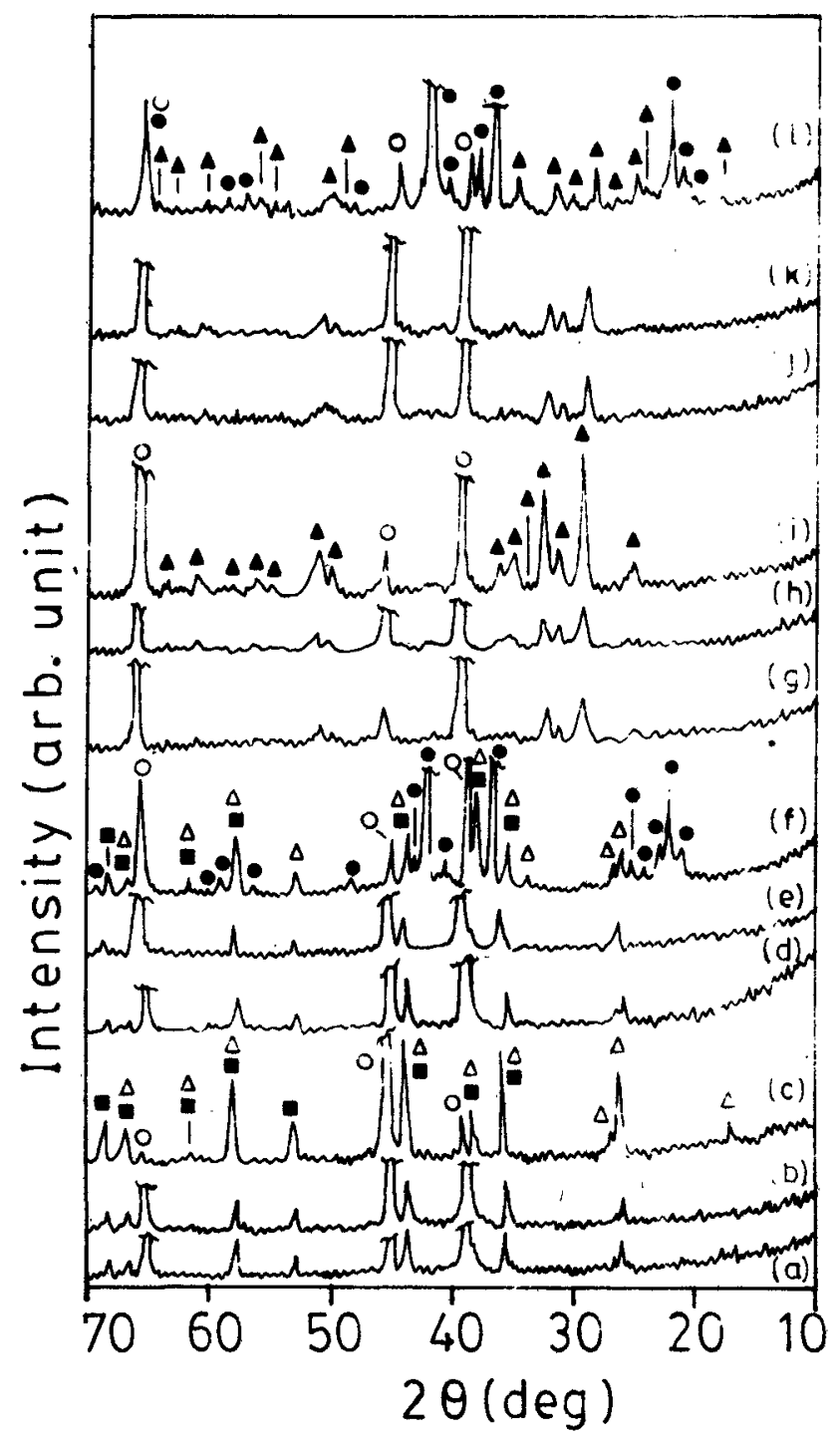

Figure 1. X-ray diffractograms of different aluminium matrix composites: (a) $\mathrm{Al}+$ mullite hot pressed at $450^{\circ} \mathrm{C}$, (b) $\mathrm{Al}+$ mullite hot pressed at $550^{\circ} \mathrm{C}$, (c) $\mathrm{Al}+$ mullite hot pressed at $610^{\circ} \mathrm{C}$, (d) $\mathrm{Al}+$ mullite hot pressed between molybdenum sheets at $450^{\circ} \mathrm{C}$, (e) $\mathrm{Al}+$ mullite hot pressed between molybdenum sheets at $550^{\circ} \mathrm{C}$, (f) $\mathrm{Al}+$ mullite hot pressed between molybdenum sheets at $610^{\circ} \mathrm{C}$, (g) $\mathrm{Al}+\mathrm{ZrO}_{2}$ hot pressed at $450^{\circ} \mathrm{C}$, (h) $\mathrm{Al}+\mathrm{ZrO}_{2}$ hot pressed at $550^{\circ} \mathrm{C}$, (i) $\mathrm{Al}+\mathrm{ZrO}_{2}$ hot.pressed at $610^{\circ} \mathrm{C}$, (j) $\mathrm{Al}+\mathrm{ZrO}_{2}$ hot pressed between molybdenum sheets at $450^{\circ} \mathrm{C}$, (k) $\mathrm{Al}+\mathrm{ZrO}_{2}$ hot pressed between molybdenum sheets at $550^{\circ} \mathrm{C}$, (l) $\mathrm{Al}+\mathrm{ZrO}_{2}$ hot pressed between molybdenum sheets at $610^{\circ} \mathrm{C}$. $\left(\mathrm{O}, \mathrm{Al} ; \mathrm{D}, \alpha-\mathrm{Al}_{2} \mathrm{O}_{3} ; \Delta\right.$, mullite; $\mathrm{O}$, $\mathrm{Al} \mathbf{5} \mathrm{Mo} ; \Delta, \mathrm{ZrO}_{2}$ ).

7 to 12 it is obvious that $\mathrm{ZrO}_{2}$ exists in cubic, tetragonal and monoclinic phases. Also at $610^{\circ} \mathrm{C}$ in this sample series $\mathrm{Al}_{5} \mathrm{Mo}$ forms at $610^{\circ} \mathrm{C}$ under high pressure conditions.

Table 1 summarizes the Vickers hardness values obtained in the case of different 
Table 1. Summary of Vickers hardness in different composites containing nanocrystalline oxide phases.

\begin{tabular}{|c|c|c|c|}
\hline $\begin{array}{l}\text { Specimen. } \\
\text { no. }\end{array}$ & $\begin{array}{l}\text { Hot pressing } \\
\left.\text { temperature ( }{ }^{\circ} \mathrm{C}\right)\end{array}$ & $\begin{array}{l}\text { Phases present in the } \\
\text { composite }\end{array}$ & $\begin{array}{c}\text { Vickers hardness }\left(H_{\mathrm{V}}\right) \\
\left(\mathrm{kg} / \mathrm{mm}^{2}\right)\end{array}$ \\
\hline 1 & 450 & $\mathrm{Al}$, mullite, $\alpha-\mathrm{Al}_{2} \mathrm{O}_{3}$ & 22 \\
\hline 2 & 550 & $=-$ & 25 \\
\hline 3 & 610 & - & 59 \\
\hline 4 & 450 (with Mo sheet) & $\because$ & 23 \\
\hline 5 & 550 (with Mo sheet) & $-"-$ & 26 \\
\hline 6 & 610 (with Mo sheet) & $\begin{array}{c}\text { Al, } \\
\underset{\alpha-\mathrm{Al}_{2} \mathrm{O}_{3} \mathrm{Mo}}{\text { mullite, }}\end{array}$ & 184 \\
\hline 7 & 450 & $\begin{array}{c}\mathrm{Al}, \mathrm{ZrO} 2 \\
\text { (Cubic + tetragonal + } \\
\text { monoclinic) }\end{array}$ & 43 \\
\hline 8 & 550 & $=-$ & 45 \\
\hline 9 & 610 & $-\because$ & 72 \\
\hline 10 & 450 (with Mo sheet) & $-"$ & 43 \\
\hline 11 & 550 (with Mo sheet) & $-"-$ & 49 \\
\hline 12 & 610 (with Mo sheet) & $\begin{array}{c}\mathrm{Al}, \mathrm{ZrO} \\
\text { (Cubic + tetragonal + } \\
\text { monoclinic), AlsMo }\end{array}$ & 215 \\
\hline
\end{tabular}

composite systems. The $H_{y}$ value for pure aluminium was measured to be equal to $14 \mathrm{~kg} / \mathrm{mm}^{2}$. It is evident from the results shown in table 1 that the hardness value increases by a factor of 4 to 5 when the nanocrystalline dispersoids of mullite or zirconia are present in the aluminium matrix and the hot pressing is carried out at a temperature of $610^{\circ} \mathrm{C}$. For treatment temperature in the range $450-550^{\circ} \mathrm{C}$ the increase is by a factor $1.8-3$. It is interesting to note that the hardness increases drastically when the $\mathrm{Al}_{5} \mathrm{Mo}$ phase is formed at $610^{\circ} \mathrm{C}$ under high pressure due to the presence of molybdenum sheet cover on the starting powder mixture. In the latter case the hardness increases by more than an order of magnitude.

The remarkable improvement in hardness of aluminium metal matrix composites containing either mullite or zirconia dispersoids with nanometer dimensions may be due to the pinning of dislocations between closely spaced particles of the oxide phase. A detailed examination of the physical mechanism will be reported elsewhere.

In summary, aluminium metal matrix composites containing sol-gel synthesized nanocrystalline oxide particles have been prepared by a hot pressing technique. The Vickers hardness values for these specimens are substantially higher than that of pure aluminium.

\section{Acknowledgement}

The work was partly supported by a grant from the Department of Science and Technology, New Delhi. 


\section{References}

Chatterjee A, Pradhan S K, Datta A, De M and Chakravorty D 1994 J. Mater. Res. 9263

Enzo S, Fagherazzi G, Benedetti A and Polizzi S 1988 J. Appl. Crystallogr. 21536

Flinn D R 1990 The new materials society (Washington DC: Burean of Mines) p. 6.1

Klug H P and Alexander L E $1974 X$-ray diffraction procedures for polycrystalline and amorphous materials (New York: John Wiley Interscience Pub.) 2nd ed. p. 689

Lampman S R 1991 Adv. Mater. Process. 13839

Lee J C and Subramanian K N 1993 J. Mater. Sci. 281578

Marsden K $1985 \mathrm{~J}$. Metals 3759

Ohtsu H 1989 in Proceedings of the Sth annual ASM/EDS advanced composites conference, Detroit, Michigan (Materials Park, Ohio: ASM Intemational) p. 187

Pandey A B, Mishra R S and Mahajan Y R 1993 J. Mater. Sci. 282943

Patuelli C and Zaffanini M 1991 in Proceedings of 18 th international symposium on shock waves, Sendai, Japan, (ed.) K Takayama (Berlin: Springer-Verlag; New York: Heidelberg) p. 387

Pradhan S K, Chatterjee A, Datta A, De M and Chakravorty D 1994 J. Mater. Res. 92474 